\title{
Jerzy Szacki o sociologii, historiografii, historii a kolektivní paměti
}

\author{
PTAL SE JaRosŁaW KiLias
}

\section{Jerzy Szacki about Sociology, Historiography, History and Collective Memory}

Hovořm s Vámi jako reprezentant časopisu Historická sociologie. Intelektuální aktivity prováděné pod hlavičkou „historické sociologie“ budí od jisté doby zvýšenou pozornost také v novém vydání Vašich Dějin sociologického myšlení se objevila kapitola o teoriích civilizace. Co podle Vás způsobilo, že začala podobná problematika znovu budit zájem?

Především bychom se měli domluvit, co budeme mít na mysli, když říkáme historická sociologie. Rozlišil bych dva, možná tř̌ různé směry. Jedním z nich by bylo pokračování sociologie, jak ji praktikovali Alfred Weber, Elias, Sorokin (v některých pracích), tedy teorie civilizace. Př́kladem druhého směru může být kniha The Sources of Social Power Michaela Manna. Oblast badatelského zájmu je i v tomto případě neobvykle široká, avšak „pracovní postup“ je zcela jiný. Nenajdeme tu totiž tolik historiosofického rozmachu, ale naopak více pracného vytváření generalizací, které se pokud možno pevně drží faktů. Nehodnotím, co je lepší a co horší, je to prostě jiný styl práce. A konečně třetí směr můžeme sledovat, pokud si vezmeme do ruky např́ílad Journal of Historical Sociology. Ve skutečnosti se jedná o výzkumy, kterým se historici v tom či onom rozsahu věnovali pod hlavičkou sociálních dějin, aniž by si přitom nutně činili nárok na sociologická bádání. Někdy to jsou jednoduše historiografické příspěvky publikované jako sociologické práce především proto, že autoři často působí na katedrách sociologie a používají poněkud jiný jazyk než historici. Odkud se však vzala podobná tvorba? Myslím si, že má stejný zdroj, jako jiné nekonvenční způsoby sociologického bádání, zejména určitou únavu z dotazníkových šetření, únavu ze sociologické rutiny, která se od dob Lazarsfelda rozšírilia po celém světě, a také chử hledat nejrůznější možnosti, jak se vydat jiným směrem, jenž by však nebyl abstraktním teoretizováním v typicky sociologickém stylu. Myslím si, že tento posun směrem k historii má v podstatě podobné příčiny jako $\mathrm{v}$ jiných př́padech posun směrem k filosofii, kulturologii, politickým vědám a mnoha jiným oblastem, které se někdy zdají slibnější než „tradiční“ sociologie.

Když jste ř́kal „dva nebo tři směry“, zaváhal jste... Proč?

Hranice mezi jednotlivými směry, které ve společenských vědách rozlišujeme, nikdy nejsou ostré a v praxi se mnohdy stírají. Jde mi jen o konstatování, že oblast tzv. historické sociologie sahá od rozsáhlých vizí společenského vývoje až po drobné studie, které bychom mohli stejně dobře zařadit do historiografie, a nikoli do „vlastní“ sociologie, má-li toto označení vzhledem k faktu, že neexistuje a nikdy neexistovala žádná jedna sociologie, vůbec nějaký smysl. Podobná hodnocení ostatně nejsou př́liš podstatná. Velmi důležité je podle mě naopak to, že charakteristickým rysem dnešní sociologie už není - Eliasem kritizovaný - „útěk k současnosti“ a sociologové stále častěji objevují přínos historie. A také kouzlo poctivé historické práce, jejíž znalost je jim potřebná nejen tehdy, když sami pracují v archivech. 
Přiznám se, že mně osobně je bližši mannovský směr. Přijde mi zajímavé, že se po hlasitých deklaracích o konci určitého typu př́běhu, metanarace, objevila celá řada „velkých př́běhü“ a že pod tímtéž názvem ,historická sociologie“ vznikají na jedné straně výzkumy mikrohistorické, ale na straně druhé i velké, komplexní teorie civilizace. Co je vlastně spojuje? Bylo heslo o „soumraku velkých naraci“ jednoduše chybné?

Ano, myslím si, že bylo. Ostatně příběh o zániku narace je také jen další velkou narací - nikoli pravdivější než jiné.

V Polsku dnes vychází rada textů Georga Simmela, co je však zajímavé, jako by se zapomnělo na jeho knihu věnovanou filosofii dějin. Zajímá mě ale odpověd’ na otázku, zda a do jaké míry jsou civilizační teorie opakováním někdejší filosofie dějin... Mám dojem, že kdyby někteř́ z autori̊ těchto teorii sáhli třeba jen po Simmelovi, znovu by si uvědomili obtiže, na jejichž existenci $v$ rámci návratu $k$ anachronickým formám narace možná zapomněli. Je tomu skutečně tak?

Samozřejmě, $\mathrm{v}$ humanitních vědách se neustále setkáváme s nejrůznějšími návraty či renesancemi. Nejsou to návraty v doslovném smyslu tohoto slova, ale některá schémata se skutečně opakují a není v tom nic neobvyklého nebo scestného. Mnoho věcí se však mění, rostou zejména požadavky kladené na kritický př́stup k faktům, s nimiž pracujeme. Převážná většina prací, jež se věnují oblasti, která nás v tomto rozhovoru zajímá, a jež jsou dnes ve společenských vědách považovány za zásadní, má více společného s historickou prací typu školy Annales než s konstrukcemi počátku 20. století či staršími, které pracovaly spíše s intuicí a ilustrativními př́́klady než s generalizacemi založenými na faktech.

To byla základní metoda: existoval určitý názor a autoři k němu uváděli vhodné př́klady sebrané, kde se jen dalo, které měly tento názor potvrdit. Dnes je však východiskem mnohem častěji spíše metodická analýza faktů a pozorování. Proti tomu samozřejmě stojí dejme tomu Huntingtonovy práce, ty jsou však napůl publicistikou a klást na ně stejná měřítka jako na texty Mannovy nebo Eliasovy by podle mého názoru bylo chybou. Jsou sice efektní, ale metoda dokazování se dá snadno zpochybnit. V tomto př́ípadě jde maximálně o svěží, bystré nápady. Mimochodem, teprve nedávno jsem díky internetu zjistil, jak špatného přijetí se v odborných kruzích dostalo Huntingtonově knize Who We Are?

$V$ posledni době jsem se vracel ke starším Huntingtonovým pracím týkajícím se sociologie armády a všiml jsem si, že i tam lze najít řadu přehnaně „snadných“ závěrů...

Jsem obecně proti takovémuto „snadnému“ zkoumání historie. At̉ už však o jeho hodnotě soudíme cokoli, společenská poptávka po tomto typu literatury ani na moment neustala. Ani tehdy, kdy filosofové ohlásili konec velkých narací, protože ani politici, ani obyčejní lidé se bez těchto „velkých narací“ nedokáží obejít. Chtějí prostě věřit, že $\mathrm{v}$ dějinách přece jen existuje jakýsi zřejmý řád.

Zdá se, že historie v poslední době získává stále větši společenský význam - a v každém př́padě ho neztrácí - ale historie, která se dostává do veřejného oběhu, je chápána, řekl bych, značně naivně. Kdybychom měli srovnat profesionální reflexi dějin s historickou publicistikou, či dokonce is odbornými pracemi těch historiků, kteři se nezabývají prŕmo 
teoretickými předpoklady této disciplíny nebo sofistikovanou metodologií, jeví se nepoměr mezi nimi mnohem výraznější, a patrně se i zvyšuje...

A zvyšuje se už dlouhou dobu. Podle mě to bude zhruba sto let, kdy přestali psát velcí historici, kteří byli vcelku všeobecně čteni tzv. inteligencí. Ted’ už není vhodná doba pro autory, kteří by byli zároveň velkými historiky i autory populárních děl. Jak se historie vyvíjí (nebo nevyvíjí - nevím) a zejména s ohledem na to, jak se proměňují její jednotlivé specializace, nemůže už historickou literaturu číst nikdo jiný než právě samotní historikové. Pokud sáhne širší veřejnost po historii, je to historie typu Jasienicy, nebo v nejlepším případě Tazbira. Takových historiků jako Tazbir, kteří píší způsobem srozumitelným i pro laiky, ale zároveň nepřestávají být vynikajícími profesionály, je však poskrovnu. Nejsem si ostatně vůbec jistý, zda ještě existuje poptávka po populární historii, jak jsme ji znali z dřívějška. To, co vyvolává zájem o historii u dnešního člověka, je - zaprvé - historie jako senzace: záhady 2. světové války, soupeření tajných služeb, spiknutí a agenti, milostné aféry a skandály atd. Je to, dalo by se říci, senzace jako každá jiná: jedni dávají přednost této její podobě, jiní raději detektivce zasazené do reálií malého městečka, anglického nebo skandinávského, jak se v poslední době stalo módou. Druhým znamením, které by naznačovalo, že lidé mají rádi historii, jsou velké podívané son et lumière, výpravné inscenace a kostýmní představení - Piotr Kwiatkowski tuto podobu historie popsal poměrně trefně jako jeden z druhů zábavy. Naopak se mi nezdá, že by historie jako drama, historie jako zdroj politických, morálních či jakýchkoli jiných dilemat... dnes sehrávala velkou roli. Stále lépe se umíme lišit v názorech i bez toho, že bychom pro to potřebovali historické kostýmy.

Ne ve všem bych s Vámi souhlasil. Je tu ještě otázka významu minulosti v kontextu politických nároků na tzv. politiky uznání nebo např́klad na ekonomické rekompenzace.

Ano, toto skutečně funguje, celý tento směr, na jehož počátku stály např́klad slavné Haileyho Kořeny. Politické precedenty - ty samozřejmě v politice fungují, připomínání dávných křivd ve jménu dnešní spravedlnosti... Australští Aboriginci, kteří se na základě událostí starých několik staletí domáhají toho či onoho kousku země, o to Vám jde? Souhlasím, tady však nejde o zájem o historii jako takovou, ale pouze o argumenty, které lze využít v nejrůznějších dnešních sporech se skutečnými či domnělými původci křivd.

Jen těžko se mohu v tomto kontextu zbavit myšlenky o eventuálních důsledcích posunu $z$ vědeckého myšleni do všeobecného povědomí o konstruovaném charakteru národních dějin jakožto určitého druhu př́běhu...

...př́íběhu konstruovaného vždy znovu v nejrůznějších verzích, přičemž pro mě je snad nejzajímavější právě to, jak se od sebe tyto různé verze liší.

Neni pro sociologa zabývajícího se reflexí nad historickou pamětí zajímavé, jak funguje mechanismus soustavného zapomínaní na tyto změny?

Samozřejmě. Normálnímu člověku je historie zapotřebí tehdy, když věří, že mu poskytne jednu a pouze jedinou pravdu - dozví se, jak to skutečně bylo. Historici si už přestali dělat iluze, že takové pravdy lze dosáhnout. Čím více vědí, tím více jsou si vědomi, jak obrovský je a bude rozsah toho, co nevědí, v čem si nejsou jistí. Prameny jsou bud’ tak nedostačující, že zcela jistě známe pouze fragmenty, které lze složit v jeden ce- 
lek různými způsoby, nebo jsou - jako v případě nejnovějších dějin - naopak tak bohaté, že je nelze uchopit a využít. Pro historika jsou tyto obtíže ohromnou výzvou, nehistorika mohou naopak odrazovat.

Zajímá mě ještě jiná věc. Připomněl jste údiv nad procesy změny a proměňujícími se obrazy minulosti, ale $v$ sociologické reflexi kolektivni paměti, přinejmenším v polské či české sociologii, ve skutečnosti scházeji analýzy společenských mechanismů této změny. Nejsou naše domácí vědni obory s to provést rekonstrukci společenských mechanismů polské národni paměti, nebo bychom měli počkat na zahranični publikace, které je zrekonstruují?

Rozlišujme, že něco jiného je pamět o minulosti, kterou má každý člověk nezávisle na tom, zda ho historie jako taková zajímá, včetně toho, čemu se věnují historici. Vždy si něco pamatujeme a neexistuje skupina nebo organizace, která by nekladla základy nějakého, byt formálního, povědomí o tom, co bylo, základy určité kontinuity, návaznosti... To však nemá př́iliš společného s historií, nebơt na rozdíl od ní pamět vše zjednoznačňuje, rozděluje na černé a bílé, na bylo - nebylo, a to na základě kritérií, která nemají př́liš společného s tím, co se dá doložit prameny. Ten, kdo nepřekročí tyto obvyklé způsoby, jak si pamatujeme minulé, je dokonale imunní vưči informacím, které nám poskytují historici, a nijak nebere $\mathrm{v}$ potaz jejich pochybnosti a neřešitelné spory. Bezmocná ostatně bývá i oficiální propaganda - což je ostatně dobře, že? Nejednou jsme přece byli svědky toho, že se zástupy propagandistů a oficiálních historiků zabývaly tím, aby lidem něco vtloukly do hlavy. A nijak to nepomáhalo - vezměme si jen celou tu námahu vkládanou v době komunismu do propagace hrdinů dělnického hnutí. To všechno vzala voda spolu se všemi dalšími „pokrokovými tradicemi“. Nemluvím jen o generacích těch, kteří se narodili př́liš pozdě, než aby s tím mohli mít cokoli společného, ale také o starších generacích, které uprostřed podobných věcí vyrůstaly. Existují polské výzkumy ze 60. let, které jasně dokládají, že se to lidí nedotklo. A na druhé straně existovalo poměrně všeobecné povědomí o tom, že došlo k něčemu takovému, jako byla Katyň, byt se jednalo o téma, které bylo tabu.

$V$ Česku jste znám především jako autor knihy Utopie...

První verze této knihy byla skutečně přeložena do češtiny, ale - pokud je mi známo - v šedesátém osmém roce, a to nebyl nejlepší moment pro její vydání. V Československu měli v té době zajímavější věci na práci!

Kniha ale nakonec vyšla $v$ prekladu Jana Sedláčka v roce 1971. Mohl byste nám ř́ci něco o současných utopiích? Jakých podob dnes nabývá utopické myšlení?

Moje kniha skutečně vyšla v češtině. Já jsem se nicméně podobnou problematikou přestal zabývat, takže když mi bylo nabídnuto nové vydání Utopií, napsal jsem knihu, která se nazývala Setkání s utopií. A to nejen proto, že vyšla v edici nakladatelství Iskry, jež měla slovo „setkání“ ve svém názvu, ale také proto, že jsem chtěl napsat jinou knihu. Rozdíly mezi oběma verzemi jsou velké. Když pak kniha vyšla v ruštině, vycházel překlad z její druhé verze. Ale i ve druhém vydání, kde jsem psal např́íklad o problematice kontrakultur a komunit, které vznikaly za dob kontrakultury, byla část věnovaná psychologickým fantaziím na téma nového člověka... Už si přesně nepamatuji, co jsem tam dodával, ale bylo toho v každém př́ípadě hodně, i když na druhou stranu 
snad až př́liš málo, pokud se na celou věc podíváme z dnešního hlediska. Vznikla např́klad řada rozmanitých a bohatých - ačkoli to nesleduji podrobně - technologických či architektonických představ... Hůře je tomu, řekl bych, se společenskými utopiemi, protože byt najdeme trochu těch „temných“, krajiny světlých zítřků, které nadejdou, vidět nejsou. Tady začala krize již mnohem dříve. Pro badatele, který se zabývá utopiemi, se ale přesto naskytlo několik zajímavých událostí, například obrovská chicagská výstava věnovaná utopiím. Mám její katalog, podařilo se jim shromáždit velké množství (nejen) ikonografického materiálu. Vyšlo také několik prací věnovaných této tematice - něco se tedy v této oblasti děje, já už jsem se jí ale přestal zabývat.

Svého času jste často psával o vztazích mezi sociologií a historií. Vlaky s názvy „historie“ $a$ „sociologie“ nejezdily vždy stejnými směry, ale mám pocit, že dnes jsou si bliže, než tomu bývalo dřive: postmoderní, narativistická historiografie, sociologický konstruktivismus... Mají dnes sociologové historikům (nebo naopak) co nabídnout?

To neprobíhá tak, že je daná disciplína jakousi nabídkou jiným disciplínám - jde spíše o to, že si badatel, nezávisle na tom, v jaké instituci nebo pod jakou nálepkou pracuje, zvolí určitý problém, zabývá se jím, čte, co je zapotřebí, a většinou jsou to práce z velmi různých vědních oborů, nejen z jeho vlastního. $V$ každém př́ípadě se i mně samotnému se kolikrát stává, že když se začnu něčím zabývat, ukáže se, že nemohu zůstat jen u sociologie. Já možná nejsem úplně typický př́klad, protože všichni vědí, jaký je ze mě sociolog (usmívá se, pozn. red.), ale zároveň je přece řada sociologů, kteří možná nedávají najevo zvláštní zájem o historii, ale nedokáží se bez historiografie obejít, protože taková je problematika, jíž se zabývají. Mám na mysli například Jadwigu Staniszkis. Mnozí sociologové podnikají takové „výlety“, stejně jako najdeme na druhé straně historiky, kteří jsou - v míře, $v$ jaké se jim to může k něčemu hodit - skvěle zběhlí v sociologické literatuře. Např́klad Jacek Kochanowicz je určitě větším znalcem sociologie než průměrný badatel věnující se sociologickým průzkumům, vydávající se za sociologa. Dochází ke vzájemnému prolínání jednotlivých disciplín a k relativizaci hranic, které mezi nimi existují... Otázka vztahu mezi disciplínami jako takovými je podle mě problémem trochu umělým. Můžeme se zamýšlet nad tím, jak tomu bylo a jak tomu eventuálně stále ještě je, ale to je v mnoha případech spíše záležitost náhody a zvyku než zásadního, meritorního rozdílu. Nemyslím si, že lze na toto téma říci něco smysluplného in abstracto. Existuje pouze jedna obecná zásada: př́liš se nezabývat tím, co je historie, co sociologie, a co ještě něco jiného.

Napadla mě tato otázka, protože mám dojem, že mnohé z problémů, s nimiž se potýkají historici-narativisté a které se týkají vazeb mezi př́během a „skutečností, by se daly vyrešit, kdybychom sáhli po konstruktivistické sociologii. Tam bychom určitě našli vhodné nástroje.

Problém je bohužel v tom, že proces vzdělávání vypadá obecně tak, že studentům je už „odmalička“ vštěpováno, aby pracovali především s texty ze „svého oboru“, takže bariéry mezi jednotlivými disciplínami bývají v praxi velmi vysoké. Vznikly sice projekty ze své podstaty interdiciplinární, např́íklad gender studies či cultural studies, ale i ty se někdy uzavírají samy do sebe jako obory více či méně soběstačné. A i jednotlivé sociologické disciplíny bývají brány tak, jako kdyby ostatní dílčí disciplíny sociologie neexistovaly. 
Čím se v poslední době zabýváte?

Jak je známo, stále fušuji do otázek spojených s nacionalismem.

Já o tom samozřejmě vím, ale ne vždy o tom musí vědět čeští čtenářri.

Pokouším se vytvořit jakési shrnutí této dnes už neuvěritelně rozsáhlé literatury; aktuálně se potýkám s určitým pojmem, jehož je využíváno, jak sám víte, až př́liš často - konkrétně s pojmem „národní kultura“. Snažím se odpovědět na otázku, o co vlastně jde (nebo šlo), když se hovoří o národní kultuře.

Mám pocit, že dnes už to není tak populární pojem...

Objevuje se stále méně odborných prací věnovaných tomuto tématu, ale to je přitom stále populární jak v politice, tak v obecném povědomí - a badatelé ho stále znovu využívají, pokud mu dokonce nepřipisují zvláštní význam. Někdy používají jinou terminologii a hovoří např́íklad o „národních idiomech“ nebo „kulturní identitě“. At tak či tak, určitá představa národních kultur stále existuje a bylo by dobře si uvědomit, o co vlastně jde. Svoji roli tu hraje i nepochybně důležitý prvek nacionalistického myšlení, který rozhodně nepatří minulosti. Je pravda, že se opírá o řadu falešných předpokladů, s nimiž se dnešní společenské vědy vypořádaly nelítostně - jde o předpoklady připouštějící, že národní kultura je relativně uzavřený systém, že má do značné míry autogenní charakter apod., všechny tyto nesmysly. Skutečně reálný je ale problém národní identity a národního kulturního dědictví. A existuje také problém národní kultury chápané jako wittgensteinovský - abych tak řekl - způsob života. Vzniklo poměrně dost nových prací, které se pokoušejí nějakým způsobem zachytit různé styly života. Je zajímavé (jak jsem zjistil), kde se těchto prací objevuje nejvíce. Vůbec ne v sociologii nebo antropologii, ale v oblasti managementu, business administration apod. Jedním slovem tam, kde tato otázka představuje praktický problém: co máme dělat, když zaměstnáváme lidi mnoha různých kultur? Jedním z autorů, kteří se tímto problémem zabývali, byl Hofstede, jehož práce sice nebyly z čistě metodologického hlediska př́liš hodnotné a mnohokrát bylo upozorňováno na zcela základní chyby, jichž se dopouštěl, ale který má zároveň celou řadu žáků. Ti někdy píší věci rádoby odborné, byt ve skutečnosti jde o jakési příručky, jak se chovat v té či oné zemi. Někdy jsou to soubory stereotypů týkajících se různých národů, ale nezlehčoval bych fakt životnosti takovýchto zájmů.

Zůstává ale faktem, že lidé v Polsku např́klad obvykle směřuji svůj pohled pod úroveň tváre lidí, které mijejí, zatímco v Česku na vás častěji hledí zpř́ma.

Existuje zajímavá práce Ladislava Holého, který je i jinak zajímavým autorem. Kniha, kterou jsem četl, se nazývá The Little Czech and the Great Czech Nation. 
Jerzy Szacki (nar. 1929), historik idejí a sociolog, emeritní profesor Varšavské univerzity. Je spojen s „varšauskou školou dějin ideji“ (mj. Bronisław Baczko, Leszek Kołakowski, Andrzej Walicki) a autorem či redaktorem několika desítek původních prací a četných překladi̊. K těm nejznámějším patř́ mj. Ojczyzna, naród, rewolucja (Vlast, národ, revoluce, 1962); Tradycja. Przegląd problematyki (Tradice. Přehled problematiky, 1971); History of Sociological Thought (Dějiny sociologického myšlení; 1979, polské vydání 1981, nové, přepracované polské vydání 2003), Liberalizm po komunizmie (Liberalismus po komunismu, 1994), přeložený do mnoha cizích jazyků, soubor studií Dylematy historiografii idei (Dilemata historiografie idejí, 1991) či výbor Sto lat sociologii polskiej (Sto let polské sociologie, 1995), jehož byl Jerzy Szacki editorem a pro nějž napsal úvod. V českém překladu Jana Sedláčka vyšly jeho Utopie (1971, originální vydání 1968). 